\title{
OSMANLI İKTİSADİ DÜŞÜNCESİNDE LİBERAL İKTİSAT: MEHMED CAVID BEY
}

\author{
LIBERAL ECONOMICS IN OTTOMAN ECONOMIC THOUGHT: MEHMED CAVID \\ BEY
}

\section{Cumali BOZPINAR ${ }^{1}$}

\section{$\ddot{O} z$}

XIX. yüzyılın sonuna gelindiğinde Osmanlı Devleti'nde liberal iktisat düşüncesinin geçerlilik kazandığı görülmektedir. Bu dönemde "geç Osmanlı liberal iktisat düşüncesinin sembolü" olarak Mehmed Cavid Bey öne çıkmaktadır. Bu çalışmada liberalizmi savunan Mehmed Cavid Bey'in görüşleri incelenmiștir. Liberal iktisat lehinde ileri sürdüğü argümanlar, teorik tutarlılığa sahip niteliktedir. Bununla birlikte, korumacılık karşıtı argümanları dikkate alındığında teorik tutarlılığı gözden kaybolmaktadır. Mehmed Cavid Bey'in açıklamalarında ortaya çıkan tutarsızlık uluslararası ticaret anlaşmaları yoluyla ticari ilişkilerin tesisini zorunlu görmesiyle birlikte değerlendirildiğinde iktisadi serbestliği mutlak anlamda önermediği kabul edilebilir. Böylece Mehmed Cavid Bey'in Osmanlı iktisadi düşünce tarihinde iktisadi liberalizmin sembol ismi olarak nitelendirilmesinin yerinde bir değerlendirme olmadığı söylenebilir.

Anahtar Kelimeler Osmanlı iktisadi düşüncesi, iktisadi liberalizm, Mehmed Cavid Bey, XIX. yüzy1l.

\begin{abstract}
By the end of the XIXth century, the idea of liberal economics had gained validity in the Ottoman State. During this period, Mehmed Cavid Bey stands out as "a symbol of the liberal economic thought of the late Ottoman State". This study examined the views of Mehmed Cavid Bey, who advocated liberalism. His arguments in favor of economic liberalism are of theoretical consistency. However, his theoretical consistency disappears when his anti-protectionism arguments are taken into account. When considering the inconsistency in Mehmed Cavid Bey's statements as necessary to establish trade relations through international trade agreements, it can be considered that he did not propose economic freedom in absolute terms. Thus, it can be said that Mehmed Cavid Bey's description as the symbol name of economic liberalism in the history of Ottoman economic thought is not an appropriate assessment.
\end{abstract}

Keywords: Ottoman economic thought, liberal economics, Mehmed Cavid Bey, XIXth Century.

\footnotetext{
${ }^{1}$ Dr., Çevre ve Şehircilik Bakanlığı (Milli Emlak Genel Müdürlüğü), cumalispontik@ gmail.com, Orcid: 00000001-8760-5253
} 


\section{GíRis}

Osmanlı iktisadi yapısının XIX. yüzyıl boyunca kapitalizm öncesi niteliğinin peyderpey kapitalist yönde değişmeye başladığı genel olarak kabul edilebilir ${ }^{2}$. Böyle olmakla birlikte kapitalizm öncesi niteliğini genel olarak koruduğu söylenebilir.

Osmanlı iktisadi yapısının kapitalizm öncesi nitelikte olmasına bağlı olarak, devletin iktisat politikası uygulamalarından değil devlet yöneticilerinin bazı iktisadi zihniyet ilkeleri çerçevesinde uygulamalarından bahsetmek mümkündür. Bu ilkelerin devlet yöneticilerinin iktisadi kararlarındaki geçerliliğinin XIX. yüzyıl boyunca peyderpey zayıfladı̆̆ 1 kabul edilebilir. Bu gelişme yavaş bir şekilde ortaya çıkan kapitalist yapısal dönüşümün beraberinde gerçekleşmiştir. Yaşanan süreçte ortaya çıkan kapitalist kurumların gerektirdiği politika araçlarının belirlenen iktisadi hedefler doğrultusunda kullanılması kapitalizm öncesi zihniyet yapısının değişmesine ve iktisadi zihniyet ilkelerinin geçerliliğinin neredeyse sona ermesine yol açmıştır. Osmanlı düşünürleri ve yöneticileri nezdinde XIX. yüzyılda liberal iktisat politikası lehinde görüşlerin ortaya çıkması bu bağlamda değerlendirilmelidir.

Osmanlı toplumunda liberal iktisat ilkelerini savunan ilk düşünür ve/veya devlet yöneticisi olmasa da bu ilkeler doğrultusunda sistematik iktisat politikaları uygulayan ilk Osmanlı düşünürü ve devlet yöneticisi Mehmed Cavid Bey (1875-1926) olmuştur.

$\mathrm{Bu}$ çalışmada Mehmed Cavid Bey'in iktisadi liberalizme ilişkin görüşleri incelenecektir. Çalışma, düşünürün İktisat İlmi (İlm-i İktisad-Mekteb-i İdadiye Mahsus) başlıklı eserinde belirttiği görüşleriyle sınırlandırılmıştır.

Çalışmada karşılaştırmalı yöntem ve kaynak tarama yöntemi kullanılmıştır. Bu kapsamda ağırlığı liberal iktisat konusunda olmak üzere Mehmed Cavid Bey’in iktisadi kabul ettiğimiz görüşleri ortaya konulup açıklanacak, bu açıklamalar gerektiğinde konu üzerine yapılmış diğer çalışmalarda belirtilen görüşlerle karşılaştırılarak değerlendirilecek ve bazı teorik çıkarımlarda bulunacaktır.

\section{MEHMED CAVID BEY VE İKTISAT: KAVRAMLAR VE SISTEMATIK}

Bağımsız bir bilim olarak iktisadın 1776 yılında A. Smith'in Ulusların Zenginliği başlıklı kitabını yayımlamasıyla ortaya çıktığı genel olarak kabul edilmektedir ${ }^{3}$. Kitap

\footnotetext{
${ }^{2}$ Bu çalışmada kullanılan liberal iktisat, kapitalist üretim ve kapitalizm öncesi üretim kavramlarının kısaca açıklanması uygun olacaktır. Liberal iktisadi görüşe göre piyasanın işleyişine herhangi bir müdahale olmadığında hem tüketiciler hem de üreticiler arasında rekabet sonucu optimal üretim/fayda düzeyi ortaya çıkar ve burada görünmez bir el tarafindan düzenlenen fiyat mekanizması geçerlidir. Kapitalizm ise bir yandan kâr amacı taşıyan değişim için yaşamın en temel gereksinimleriyle ilgili olanlar dâhil tüm mal ve hizmetler üretiminin, diğer yandan da meta durumuna gelen emek gücü dâhil tüm üretim faktörlerinin piyasaya bağımlılığının geçerli olduğu bir üretim tarzıdır. Kapitalizm, önceki üretim tarzlarından, üreticilerin üretim araçlarının elde edilmesinde piyasaya bağımlı olmalarıyla ayrılmaktadır. Kapitalizmde artı değere el koyanlar, kapitalizm öncesi yapılardaki benzerlerinin -örneğin feodalizmde derebeylerin- başvurduğu askeri, siyasi ve adli güç gibi doğrudan baskı yoluyla "ekonomi dışı" el koyma güçleri yerine piyasa mekanizmalarına dayanmak zorundadırlar. Piyasaya bağımlılık temelinde ayırt edilen bu sistem, rekabet ve kâr maksimizasyonuna ilişkin gerekliliklerin yaşamın temel kuralları olduğuna işaret eder. Bu kapsamda kapitalizm, rekabet edebilmek için üretim maliyetlerinin düşürülmesi amacı doğrultusunda emek üretkenliğinin icat edilen teknik araçların devreye girmesiyle artırıldığı bir sistemdir. Başka bir deyişle kapitalizmde üretim faaliyetleri zorunlu bir biçimde rekabete dayalı olarak ve piyasaya bağımlı bir şekilde gerçekleşir (Bozpinar, 2018: 1).

${ }^{3}$ İktisat üzerine çalışmaların Smith'in Ulusların Zenginliği başlıklı çalışmasından yarım yüzyıl yıl önce Fransa'da yapıldığı kabul edilebilir. R. Cantillon (1680-1734), Ulusların Zenginliğgi'nin yayımlanmasından 40 yıldan fazla bir süre önce iktisat üzerine ilk eserini yazmıştır. Bunun yanında C. Gide, F. A. Hayek ve W. S. Jevons bir bilim olarak iktisadın öncüsü olarak Cantillon'u kabul etmişlerdir (Rothbard, 1995: 345, 347). İktisat biliminin kurucusunun Sir W. Petty (1623-1687) olduğu ve değer konusunda Cantillon'un Petty'i izlediği de belirtilmektedir (Ulutan, 1978). Diğer taraftan Smith'in iktisadi analizinin öncülerinin bulunduğuna dair muhtelif
} 
yayınlandığında Batı Avrupa toplumunda iktisadi kavramlar yüzyıllardır yerleșik durumdadır. Osmanlı Devleti'nde ise reform dönemi olarak kabul edilen III. Selim döneminde bile iktisadi nitelikteki reformlar herhangi bir iktisadi teoriye dayandırılmamış olup Osmanlı yöneticilerinin kendi dillerinde iktisat kitaplarının yayımlanması için 60 yılın geçmesi gerekmiştir (Kılınçoğlu, 2012: 45).

Osmanlı Devleti'nde 1860'lara kadar iktisat üzerine özet diyebileceğimiz boyutta çeviriler yapılmıştır. 1860'larla birlikte karşılığı kavram üzerinde herhangi bir uzlaşı olmaksızın gazete ve dergilerde iktisat bilimine ilişkin yazılar yayımlayan bir kuşağın ortaya çıktı̆̆ belirtilmektedir: İbrahim Şinasi, Münif Paşa, Mehmet Şerif Efendi ve Ohannes Efendi (Kılınçoğlu, 2012).

Osmanlı iktisadi sorunlarına ilişkin iktisadi nitelikte ilk çalışmanın Mehmet Şerif Efendi'nin Tercüman-1 Ahval gazetesinde yayımlanan sanayileşmeden yana makalesi olduğu belirtilmektedir (Kılınçoğlu, 2012: 54). İktisadi korumacılığı ise ilk olarak Ahmet Mithat Efendi'nin (1864-1923) savunduğu anlaşılmaktadır (Kılınçoğlu 2012: 64). Akyiğitzade Musa Bey (1865-1923), Ahmet Mithat Efendi'nin izinden giderek daha sistematik bir şekilde korumacılığ1 savunmuştur (Kılınçoğlu, 2012: 86).

Yüzyılın tamamında iktisadi kavramlar üzerinde bir mutabakat sağlanmamasına bağlı olarak tam bir kavram kargaşası yaşanmıştır. Bu kapsamda 1896'da yayımlanan Illm-i Servet veyahut İlm-i Iktisat başlıklı eserinde Akyiğitzade Musa Bey'in F. Quesnay ve A. Smith için tutumlu anlamında muhdesid sıfatını, büyük sanat ashâbı ve fabrikatör kelimelerini kapitalist yerine ve faydalı şey ile serveti aynı anlamda kullandığı belirtilebilir (Akyiğitzade, 2016: 74). Kılınçoğlu (2012: 104) da Süleyman Sudi'nin 1888'de yayımlanan Defter-i Muhtesid başlıklı eserinde "ilm-i iktisad"1 "kamu maliyesi" anlamında, "ilm-i tedbir-i servet" kavramını ise "ekonomi politik" anlamında kullandığını belirtmektedir. Başka deyişle iktisat kavramının kamu maliyesi anlamında kullanıldığı anlaşılmaktadır.

Diğer taraftan Osmanlı Devleti'nde XIX. yüzyılın sonuna gelindiğinde liberal iktisat düşüncesinin ağırlık kazandığı görülmektedir. Burada "geç Osmanlı liberal iktisat düşüncesinin sembolü" olarak Mehmed Cavid Bey öne çıkmaktadır.

Mehmed Cavid Bey, Klasik İktisat yanlısı Sakızlı Ohannes ve Namık Kemal'den beri yerleşik liberal iktisat görüşünü savunmuştur ${ }^{4}$. İktisadi kalkınma için dünya ekonomisiyle bütünleşmeden yana olmuştur. Bu bağlamda ülke içindeki sermaye yetersizliklerinin yabancı sermayeli şirket ve bankaların korunması ve desteklenmesi yoluyla giderileceğini savunmuştur. Bununla birlikte devletin dağılıyor olması, milliyetçi akımların güç kazanması ve I. Dünya Savaşı gibi gelişmeler Mehmed Cavid Bey'in düşüncelerinde değilse bile uygulamalarında önemli değişiklere yol açmıştır. Bu kapsamda kapitülasyonları kaldırma teşebbüsleri, Osmanlı İtibar-1 Milli Bankası'nın kurulmasına öncülük etmesi ve İstihlak-i Milli Cemiyeti'ne girmesi belirtilebilir (Çakmak, 2001: IX).

argümanlar ileri sürülmektedir. Ayrıntılar için bk. Johnson (1937), Rothbard (1995), Aspromourgos (1996), Redman (1997), Steiner (2003), Murphy (2009), Eren (2010), Eren (2011) ve Bilir (2019).

${ }^{4}$ Osmanlı iktisadi düşüncesine liberal iktisadi anlayışın girişi II. Mahmud Dönemi’nin sonlarına rastlar. Bu tarihlerde İngiliz büyükelçiliğinde çalışan D. Urquhart, İngiltere'nin ekonomi politikalarını Osmanlı Devleti üzerinde de etkili kılma çabası içinde olmuştur. Mısır sorununun İngiltere'nin desteğiyle çözülmesi, serbest ticaret konusunda Osmanlı yönetiminin baskı altına alınmasında etkili olmuştur. Ayrıntılar için $b k$. Bozkurt (2019). Diğer taraftan Osmanlı Devleti'nde liberal iktisat düşüncesinin gelişmesinde Abdülmecid Dönemi'nde 1859'da İstanbul'da kurulan Mekteb-i Mülkiye'de okutulan derslerin büyük etkisi olmuştur. II. Abdülhamit Dönemi'nde liberal iktisat anlayışının devletin resmi ideolojisi olduğu belirtilmektedir (Cengiz, 2012: 23-4). Osmanlı iktisadi düşüncesinin gelişimine ilişkin olarak ayrıca $b k$. Sayar (2013). 
İktisat İmi başlıklı kitabın genel özelliklerinin anlatılıp buna göre bazı değerlendirmelerde bulunulması Mehmed Cavid Bey'in serbest iktisat düşüncesinin anlaşılabilmesi ve değerlendirilebilmesi açılarından uygun olacaktır.

Kitapta "ekonomi politik" yerine "servet ilmi" kullanımının yanlışlıkları ortaya koyulduğu gibi "iktisat"ın diğer bilim dallarıyla ilişkisi bağlamında doğal bilimler ve sosyal bilimlerle olan ilişkisine değinilmiştir (Çakmak, 2001: X). Bilimsel bir eser nasıl kavramsal çerçeveden başlarsa burada da öyle yapılmıştır.

"Ekonomi politik" karşılığı olarak "servet ilmi” kullanımının yanlışlığına dair ilk olarak, bu yanlışlığın iktisat bilimiyle uğraşanların mutlaka servet sahibi olması gerektiği şeklinde bir algıya yol açtığını belirtmiştir. Şöyle ki iktisat bilimiyle uğraşanların servet miktarlarının düşük olması durumunda bu bilimin gerekliliği ve faydası noktalarında menfi düşünülmesine yol açtığını kabul etmiştir (Cavid Bey: 2001, 3). Bu sebeplerden dolayı servet bilimi kavramının kullanılmasından vazgeçilmesini önermiştir. Diğer taraftan ekonomi politik kavramının kullanımı da uygun bulmamıştır. Buradaki gerekçesi iktisat biliminin siyaset ile bütünlük içinde olduğu zannını uyandırdığı olmuştur. Bununla birlikte iktisadın tarihle ilişkisi bağlamında değerlendirmeleri bu açıklamalarıyla çelişkilidir. Şöyle ki tarihin incelediği konular arasında devletlerin genişleme sebeplerinin özellikle iktisadi nitelikte olduğunun araştırılması da bulunduğunu, bunun için de iktisadi ilkelerin bilinmesi gerektiğini belirtmiştir (Cavid Bey, 2001: 4). Dolayısıyla iktisat ile siyasetin iç içe geçtiğini farkında olmadan kabul etmişstir.

Kitapta iktisat tarihi bağlamında Fizyokratlar, Merkantilistler ve Klasik İktisatçılar anlatılmıştır (Çakmak, 2001: X). Sonrasında iktisadın tanımı yapılıp toplum için gerekliliği belirtilmiş ve çalışma alanları açıklanmıştır (Çakmak, 2001: X-XI). Bu alanlar aynı zamanda kitabın bölümlerini oluşturmuştur: Servetin üretilmesi, bölüşümü, kullanımı ve tüketilmesi (Çakmak, 2001: XI). Burada ilginç olan kavram kargaşasının devam ettiğinin bir işareti olarak kabul edilebilecek maliye bilimiyle ilgili açıklamalara da kitapta yer verilmesidir.

İktisadın tanımı konusunda Mehmed Cavid Bey, Paul Leroy Beaulieu'nun şu tanımını vermiştir: "İktisat ilmi, tabiatın insanların kendiliğinden bahşetmediği faydaları ortaya çıkaran ve bunlardan faydalanmak için kullanılacak olan, insanların çalışmalarının tesir ve faaliyetlerinin suretini gösteren kanunlardan bahseden bir ilimdir”. Başka bir tanım olarak iktisat ilminin servetin üretilmesi, bölüştürülmesi, kullanılması ve tüketilmesine sebep olan kanunların incelenmesi olduğunu belirtmiştir (Cavid Bey, 2001: 11). İktisadın faaliyet alanını dört kısma ayırmış ve bunların her birinin servetin bir aşaması olduğunu belirtmiştir: 1) Servetin üretilmesi (istihsal-i servet), 2) Servetin bölüşümü (inkısam-1 servet), 3) Servetin kullanılması (tedavül-i servet) ve 4) Servetin tüketilmesi (istihlak-1 servet) (Cavid Bey, 2001: 12).

Burada kavram kargaşasının bir örneği daha görülmektedir. "Milli gelir"i ifade etmek üzere "servet" kelimesi kullanılmıştır. Bundan başka ihtiyacın sonucu insanların çalışması ve bu yüzden "servet" ürettiklerinin belirtilmesidir (Cavid Bey, 2001: 13). Burada "servet", "mal ve hizmet" yerine kullanılmıştır.

Kitabın "servetin kullanılması" başlıklı bölümünün bir kısmında "serbest mübadele" ve "korumacılık"la ilgili olarak karşılaştırmalı bilgi verilmiştir (Çakmak, 2001: XI). Bu konu aşağıda ayrıntılı bir şekilde anlatılacaktır.

Mehmed Cavid Bey'in ayırt edici özelliği kitabında krize de yer vermiş olmasıdır. Bundan başka; korumacılık lehine argümanlara ilişkin karşı açıklamaları -serbest mübadele lehine- mevcuttur. Diğer taraftan küçük işletmelerin büyükler lehine korunmasını, koruma maliyetini ön plana çıkararak kabul etmezken korumacılık ve milli iktisat taraftarlarına karşı - 
milli sanayinin gelişmesini ve korunmasını savunanlara karş1- bazı açıklamalarda bulunmuştur. Ayrıca sömürgecilik-kolonizasyon lehinde ekonomik argümanlar ileri sürmüş, tekele karşı olduğunu "en kötü tekel, devlet tekelidir" şeklinde ifade etmiş ve toprak reformu ve küçük çiftçiliğe karşı görüşler ortaya koymuştur. Bunun dişında üretim faktörleri analizi günümüz içeriğine sahip olup girişimcinin önemini vurgulamıştır (Çakmak, 2001: XII). İlginç bir nokta vergileme analizinin liberal iktisat yanlısı olduğunu göstermesidir: Etkin vergilemenin düz oranlı ve gelir üzerinden yapılması gerektiği ve artan oranlı vergilemenin ve özellikle sermayenin vergilendirilmesinin ekonomiyi sıkıntıya sokacağını ileri sürmüştür (Çakmak, 2001: XIII).

Diğer taraftan kitabın çevirisinde sadeleştirme yapıldığı ve bu kapsamda "sanayi” ve "sanat" kelimelerinin bazen sektör ve meslek, bazen de günümüzdeki anlamlarıla kullanıldığı belirtilmektedir (Çakmak, 2001: XIII). Bu durum iktisat teorisi bağlamında Mehmed Cavid Bey'in yetersizliğini göstermektedir ${ }^{5}$. Şöyle ki zanaat üretimi kapitalizm öncesi üretim örgütlenmesidir. Osmanlıca "zanaat" kelimesinin çoğulu "sanayi"dir". Böylece sanayi kelimesinin sektör anlamında kullanılması Osmanlı ekonomisinin kapitalizmin son aşaması olan sanayileşme aşamasına geçtiği şeklinde çıkarıma yol açmaktadır.

Mehmed Cavid Bey buhran kelimesini de kriz kelimesini de "üretim ile tüketim arasındaki dengenin bozulmasından dolayı ortaya çıkan olağanüstü haller" anlamında kullanmıştır fakat buhran kelimesini tercih etmiştir. Kıtlıkları "gelişmemiş ülkeler" dediği az gelişmiş ülkelere özgü kabul ederken kıtlıkların tarımda uzmanlaşmış ülkeler için de geçerli olduğunu kabul etmiştir. Krizleri ticaret ve mali buhranlar ile iktisadi buhranlar olmak üzere iki başlıkta incelemiştir (Cavid Bey, 2001: 309).

Ticari ve mali buhranlarla ilgili açıklamaları günümüzün banka-kredi krizlerine benzemekte olup Marxist iktisatçıların kriz açıklamalarını çağrıştırmaktadır ${ }^{7}$ (Cavid Bey, 2001: 309-11). Bununla birlikte Mehmed Cavid Bey Marx'tan veya herhangi bir Marxist iktisatçıdan bahsetmemiştir. Bundan başka krizin kaynağı olan bankalara yönelik herhangi bir devlet gözetimini ve müdahalesini önermemiştir. Bununla birlikte şu açıklaması konjonktür teorisini çağrıştırmaktadır:

"...Ticari ve mali buhranların zamanı belli olacak şekilde, hemen hemen on senede bir meydana geldiği görülmektedir. Bazen savaşların sebep oldukları büyük borçlanmalar, vergilerin şiddeti, umumi gelirin azalması dolayısıyla buhranların oluşumuna sebep oldukları gibi, nakit paradaki büyük değişim de fiyatlarda dehşetli bir değişim meydana getirerek 1stırap devirlerini ortaya çıkarabilir..." (Cavid Bey, 2001: 311).

$\mathrm{Bu}$ paragraftaki acıkmalarıyla ilgili olarak da herhangi bir kaynak göstermemiştir. Bize göre okuyucuya şu içerikte bir mesaj vermiştir: Liberal iktisat ilkesi iktisadi hayatta girişimcinin kazanmayı da kaybetmeyi de olağan karşılayacak bir zihniyete sahip olmasını gerektirir ve dolayısıyla devletin müdahalesinden bahsedilemez.

İktisadi buhranları ise üretim krizi gibi açıklamıştır:

\footnotetext{
${ }^{5}$ Mehmed Cavid Bey kapitalizm öncesi aşamadan kapitalizme geçişe ilişkin olduğu kadar kapitalizmin gelişim aşamalarına ilişkin olarak da kitabında herhangi bir açıklamada bulunmamıştır.

${ }^{6}$ Zanaat kelimesinin sözlük anlamı "İnsanların maddeye dayanan gereksinimlerini karşılamak için yapılan, ögrenimle birlikte deneyim, beceri ve ustalık gerektiren iş”tir (Zanaat, t.y.). Sanayi kelimesinin sözlük anlamı ise "sanatlar, zanaatlar"dır (Develioğlu, 1978; Kanar, 2008). Diğer taraftan sınai kelimesi “yapay, insan yapısı; sanat ile ilgili; sanayi ile ilgili”" anlamlarına gelmektedir (Develioğlu, 1978; Kanar, 2008). Dolayısıyla 'Osmanlı sanayisi’ kavramı esasında Osmanlı zanaat üretimini ifade etmektedir.

${ }^{7}$ Burada benzerlik üretim fazlasına talebin kredi yoluyla sağlanmasıdır. İlerleyen süreçte kredi mekanizması da tıkanır. Ayrıntılar için bk. Mandel (2008: 321-349).
} 


\begin{abstract}
"Üretim sahalarında yani fabrikacılıkta, ziraatta, deniz ve kara ulaşımında birdenbire, pek umumi ve pek derin ilerlemelerin olduğu vakitlerde, fiyatın ve rekabetin şimdiki şartları değişerek birçok üreticilerde bir şaşkınlık görülür...
\end{abstract}

Mesela, sanayi üretimlerinde birdenbire artış görülünce talebin de derhal aynı oranda artması mümkün değildir. Bunun için bazen alışkanlıkların değişmesi gerekir ki bu da zamanın geçmesine bağlıdır. Üretimdeki artışın tedarik kaynaklarında güçlüklere sebep olmaması, yani buhran doğurmaması, mutlaka aşamalı olmasına bağlıdır. Böyle zamanlarda kaynaklar, ancak eşyaların tedariki için gereken fedakarlığın azalması, yani fiyatın düşmesi şartıyla genişleyebilir...

...Özetle; üretimlerde ve nakliye vasıtalarında halkın zevk ve ihtiyaçlarında meydana gelecek hızlı değişim, iktisadi bir buhranın ortaya çıkmasına sebep olur. Bu buhranın şiddet ve devamı, değişimin önem derecesiyle uyumlu bulunur..." (Cavid Bey, 2001: 311-2).

Bununla birlikte iktisadi buhranlara ilişkin açıklamalarının ticari ve mali buhranlara ilişkin açıklamalarından farklı olarak bütünsellik göstermediği belirtilebilir. Şu ifadeleri gerçekten bu konudaki “dağınıklığını” göstermektedir:

\begin{abstract}
"Keza vergilerin tarhında esaslı düzenlemeler icra edilirse ve faiz miktarı hızlı olarak düşüşe uğrayacak olursa, cemiyetin zengin sınıfının gelirinin azalması sebebiyle bunlar üretimlerini azaltırlar. Üreticiler, kaynakların azaldığını görürler. Bundan da bir buhran ortaya çıkar. Bu gibi müşkül zamanlarda üretimleri şimdiki şartlara uygun hale getirmek gibi nazik, ince bir mesele karşısında bulunurlar. Ikktisadi buhranlar belirli bir zamanda ortaya çıkmayıp ara sıra meydana gelir. Fakat devamlarl daha fazla olur." (Cavid Bey, 2001: 312).
\end{abstract}

İktisadi buhranlara da çözüm önerileri getirmemesini liberal iktisat ilkesi çerçevesinde ticari ve mali buhranlara ilişkin açıklamalarımız kapsamında değerlendirebiliriz.

\title{
LIBBERAL İKTISAT VE MEHMED CAVID BEY
}

Mehmed Cavid Bey, bir ülkenin gümrük kapılarının diğer ülkelerin mallarına serbest bir şekilde açık bulundurulması usulüne "serbest mübadele" demiştir (Cavid Bey, 2001: 268). $\mathrm{Bu}$ usulü uygulayan ülkelerin ya yabancı mallardan -bazı istisnalarla- hiç vergi almadıklarını (vergiye tabi ürün sayısı 8-10 olan İngiltere'nin böyle olduğunu) ya da bu malları devlet geliri elde etmek amacıyla çok az bir vergiye tabi tuttuklarını belirtmiştir (Cavid Bey, 2001: 269). Bir ülkenin gümrük kapıları yabancı mallara karşı ya tamamen kapalı olur ya da bunların ülke içine girişine oldukça ağır vergilere tabi olmaları şartıyla için verilirse bu usule de "himâye usulü yani korumacılık” demiştir (Cavid Bey, 2001: 269).

Burada liberal iktisat ilkesi uygulandığında dahi vergilerden bahsetmesi söz konusu ilkenin mantığıyla tutarsızlık sergilemektedir. Diğer taraftan korumacılık konusunda ise çok keskindir. Vergilerin ağır olmasını kabul etmesinin yanında bunun zaman içinde ülke üretim sektörlerinin güçlenmesine paralel olarak tedricen düşürülüp sonrasında ortadan kaldırılmasını da önermemiştir. Bu yönüyle Osmanlı iktisadi düşünce tarihinde korumacılığın sistematik savunucusu Akyiğitzade Musa Bey'den daha radikaldir. Şöyle ki Akyiğitzade Musa Bey kavramsal olarak ifade etmese de genç sanayiler hipotezi kapsamında geçiş dönemi korumacılı̆̆ını kabul etmiştir ${ }^{89}$.

Mehmed Cavid Bey insan tabiatı, yeryüzündeki zıtlıklar ve iktisadi ilkeler gereği serbest mübadele usulünün korumacılıkla karşılaştırılamayacak kadar çok tercih edilmesi gerektiğini ileri sürmüştür. Buna rağmen, bulunduğu dönemin devlet yöneticileri dâhil kamuoyu nezdinde korumacılığın ülke menfaatine uygun olacağının zannedildiği ve bu

\footnotetext{
${ }^{8}$ Ayrıntılar için $b k$. Akyiğitzade (2016).

${ }^{9}$ Diğer taraftan Osmanlı iktisadi düşünce tarihinin seyrine bakıldığında 1908 yılına kadar korumac1-liberal iktisat tartışmasının büyük ölçüde ders kitaplarının sayfalarında yer aldığı, bu tarihten itibaren ise dergi ve günlük gazetelerde geniş bir okur kitlesine yansıdığı belirtilmektedir (Toprak, 2019: 81).
} 
zannın sonucunda yanlış bir politika izlendiğini belirtmiştir. Bu bağlamda serbest mübadelenin başlıca 5 büyük faydasından bahsetmiştir.

Illk olarak serbest mübadele ülkede üretimi yapılmayan ve ülkede bulunmayan malların ülkeye girişinin sağlanmasıyla dışarıdan ucuz mal tedariki yoluyla sermayenin ülke içi uzmanlaşmış sektörlere kanalize edilmesine yol açacağını kabul etmiştir (Cavid Bey, 2001: 269-70).

İkinci olarak doğal afet dolayısıyla ortaya çıkan ülke içi arz eksikliğinin serbest mübadele yoluyla telafi edileceğini belirtmiştir. Bunu ülkeler arasında bir nevi "karşılıklı sigorta" olarak kabul etmiştir. Doğal afet zamanlarında ithalat yoluyla tedariğin korumacılıkta mümkün olmayacağını zira bu durumda ülkelerin üretimlerini kendi ihtiyaçlarına göre belirlediklerini belirtmiştir. Dahası korumacılık uygulayan bir ülkenin böyle zamanlarda arz eksiğini dışarıdan tedarik etse bile bunun için çok yüksek bedel ödeme mecburiyetinde olacağını ileri sürmüştür.

Üçüncü olarak serbest mübadele sayesinde iş bölümünün uluslararası düzeyde gerçekleşeceğini kabul etmiştir. İş bölümünün yol açtığı uzmanlaşma sayesinde üretim maliyetinin düşeceğini belirtmiştir (Cavid Bey, 2001: 270). Böylece tüm ülkelerin kazançlı çıkacağını ileri sürmüştür (Cavid Bey, 2001: 271).

Dördüncü olarak serbest ticaretin her türlü ilerlemenin kaynağı olan rekabeti teşvik ederek "gayretin oluşumunu sağlayacağı"nı belirtmiştir. Bu kapsamda tekelci eğilimlerin de oligopolcü yapılanmaların da engelleneceğini kabul etmiştir (Cavid Bey, 2001: 272).

Beşinci olarak serbest ticaretin ülkeler arasında yakınlaşmaya yol açarak husumetin ortadan kalkmasını ve ihtilafların çözülmesini ya da azalmasını sağladığı gibi ülkelerin bir örgüt çatısı altında yer almasına bağlı olarak savaşları da engelleyebilme potansiyeli taşıdığını kabul etmiştir (Cavid Bey, 2001: 271-2).

Serbest mübadelenin faydalarına ilişkin kendi argümanlarından başka korumacılık lehindeki argümanları da sıralayıp bunlara karşı serbesti lehinde açıklamalarda bulunmuştur.

İlk olarak korumacılık lehindeki "serbest mübadele bütün insanlığın menfaatlerini düşünmekteyken himaye usulünün mensup olduğu ülke ve milletin ilerlemesini gerekli kıldığ ve tabiidir ki bir ülkeye, başkalarının menfaatine olarak kendi istifadesini terk etmesinin teklif edilemeyeceği" argümanına karşı yukarıda sıraladığımız kendi argümanlarını ileri sürmüştür (Cavid Bey, 2001: 272).

İkinci olarak "Bir ülkenin ürünleri yabancıların rekabetinden korunmazsa yavaş yavaş sanayisinin gerileyerek bir süre sonra ortadan kalkacağı, bu durumda insanların iş bulmak için göç etmelerine bağlı olarak ülke nüfusunun azalacağı ve ülke sermayesinin tükeneceği” argümanına karşı yabancı malların rekabetinden korunmanın ülke içinde her türlü ilerlemeyi engelleyeceği ve fiyatları yükselterek tüketicilerin fazla fedakârlıkta bulunmasına yol açacağını ileri sürmüştür. Dahası sanayinin ilerlemesinin de korumacılık sayesinde değil sermaye ile bilim ve eğitimin yayılmasıyla ortaya çıkacağını kabul etmiştir (Cavid Bey, 2001: 272-3). Burada genç sanayi hipotezinden bahsetmemesi savunmasını zayıflatmıştır.

Üçüncü olarak teoriden açıkça bahsetmekse de genç sanayi hipotezine karşı olduğu söylenebilir. Bu, korumacı argümana ilişkin şu ifadelerinden anlaşılmaktadır:

\footnotetext{
"Her toplumun tam bir iktisadi canlılık oluşturması lazımdır; milletleri ziraatçı, sanatçı, tüccar diye kısımlara ayırmak doğru değildir. Bir millet, tamamen bir şahıs ile kıyaslanamaz. Milli hayat da ziraat, ticaret ve sanatın güvenine layık olmazsa söner; yok olur gider. Bir toplum ancak ziraatı, sanatı ve ticareti kazandığı zaman olgunluk yaşına varır. Fakat bu yaşa gelmek için korunma tedbirlerine ihtiyacı vardır ki bu da himaye usulüdür." (Cavid Bey, 2001: 273).
} 
Kısaca ülkenin az sayıda da olsa rekabet üstünlüğü olduğu sektörlerde uzmanlaşması gerektiğini ileri sürmüştür.

Dördüncü olarak "Himaye usulü, bir ülkenin siyasi menfaatlerinin gereğindendir." argümanına karşı siyasi faktörden kaynaklı olarak bir ülkenin üzerinde tam kontrolünün olacağı sektör sayısının tersane, tophane, makine ve teçzihat üretim tesisi gibi sınırlı olduğunu fakat bunların bile en zor zamanlar dâhil dışarıdan tedarik edilmesinin mümkün olduğunu kabul etmiştir (Cavid Bey, 2001: 273).

Beşinci olarak "Himaye usulü, ülkede yeni üretim sahaları meydana getirir." argümanına karşı sırf yerli üretim olsun diye verimliliğine bakılmaksızın sektör çeşitlendirilmesi durumunda bunun üretim maliyetlerinin karşılanmasının sıkıntılı olduğunu belirtmiştir (Cavid Bey, 2001: 274).

Altıncı olarak "Himaye usulü, yerli işçiyi geçindirir." argümanına karşı korumacılığa bağlı olarak fiyat artışının bu kazanımı telafi edeceğini, fiyat artışının tüketimi ve dolayısıyla üretimi düşürmesine bağlı olarak işçiyi işsiz bırakacağını ve himaye edilen sektör kârlı olacağından sermaye ve işçinin suni olarak kârlı hale getirilen bu sektöre yöneleceğini, bunun sonucu olarak burada rekabetin artarak işçi ücretinin düşeceğini ileri sürmüştür (Cavid Bey, 2001: 274-5). Burada korumaya bağlı olarak korunan sektörde ortaya çıkan rekabetin işçi ücretlerini düşürmesi şeklinde kurulan illiyet bağının uygunsuz olduğu belirtilmelidir.

Yedinci olarak "korumacılığın ülkede serveti arttıracağı" argümanına karşı bunun yanlış olduğunu "bütün milletin zararına olarak birkaç kişinin zengin olmasına sebep olur" diyerek kabul etmemiştir.

Sekizinci ve son olarak ABD ve Almanya'nın korumacılıkla kalkındığına karşı ise bu ülkelerin ilerlemelerinin halkının çalışkanlığı ve girişimci gücüyle topraklarının verimli olması ve maden kaynaklarının zenginliğine bağlı olduğunu belirtmiştir. Dahası korumacılık uygulanmamış olsaydı bu ülkelerin mevcut durumdakinden daha fazla ilerlemiş olabileceklerini ileri sürmüş̧tür (Cavid Bey, 2001: 275). Bu son durumda Mehmed Cavid Bey aslında korumacılığın yol açacağı olumsuzluklara ilişkin olarak daha önce belirttiklerinin tersinin korumacılık sayesinde gerçekleştiğini farkında olmadan kabul etmiş olmaktadır.

Mehmed Cavid Bey'in korumacılığa ilişkin farkında olmadığı başka kabulleri de söz konusudur. Borçlanmaya ilişkin argümanları korumacılığın zorunlu olduğunu göstermektedir. $\mathrm{Bu}$ durum İktisat İlmi kitabının sistematiğindeki elzem bir tutarsızlıktır. Tutarsızlık temel olarak zorunlu yatırımlar için borçlanmanın kabulü merkezindedir. Burada korumacılık, belli sektörleri oluşturmak üzere borçla elde edilen kaynakları kullanmak suretiyle devletin piyasaya müdahalesi olarak anlaşılabilir ${ }^{10}$.

Başka bir husus bugünkü deyimle dış ticarette misilleme üzerine Mehmed Cavid Bey’in görüşlerindeki eksikliktir. Mehmed Cavid Bey, mallarına karşı korumacılık uygulanan ülkenin de aynı şekilde hareket etmek zorunda kalacağını belirtir. Böylece savaşın eşiğine gelineceğini ve dolayısıyla serbestliğin güvenilir bir ticaret sağladığı halde korumacılığın bir savaş politikası olup uluslararası birliği bozduğunu kabul etmiştir (Cavid Bey, 2001: 276). Genç sanayi hipotezi çerçevesinde analiz edildiğinde böylesi tehlikelerin ortaya çıkmayacağı belirtilebilir. Şöyle ki potansiyeli olan üretim sektörü ülke içi piyasada başlarda nispi pay sahibi olup yabancı mallar piyasa payı azalmış bir şekilde yine satılmaya devam eder.

Mehmed Cavid Bey serbest mübadelenin faydalarına ilişkin argümanlarından ve korumacılık lehindeki argümanlara karşı da serbesti lehinde uzun açıklamalarda bulunduktan sonra ilginçtir ki genç sanayi hipotezine benzeyen şöyle ifadeler kullanmıştır:

\footnotetext{
${ }^{10}$ Ayrıntılar için $b k$. Cavid Bey (2001, "Borçlanma" başlıklı bölüm).
} 


\begin{abstract}
"Acaba bazı olağanüstü hallerde bir ülke için serbest ticaret düsturundan geri dönmek uygun mudur?

...Buraya kadar verdiğimiz açıklamalar, gayet serbest bir gümrük politikası kabul etmek ve milletlerarası ilişkileri daima kolaylaştırmaya çalışma lüzumunu göstermektedir. Bunun için gümrük vergileri gayet ölçülü olarak alınmalı...bütün ham maddeleri, gıda maddelerini, gübreleri vergisiz ithal etmeli; ülkede ilerlemesi mümkün olmayan ve bundan dolayı daima hükümetin yardım parasıyla geçinecek olan sanayi ürünleri için himaye usulüne kesinlikle başvurulmamalıdır. Buna rağmen bir veya birkaç sanatın, ülkenin iklimi, halkın alışkanlıkları, kabiliyetleri dolayısıyla içerde yetişmesi, ilerlemesi ihtimali mevcut olup da hal ve sebeplerin geçmişteki ayrılıklardan dolayı oluşmadığı görülürse, bu gibi sanayinin geçici bir müddet için yabancılarla rekabet tesirinden korunmasına izin verilebilir. Bunda da halkın zarara uğratılmış olacağı muhakkaktır. Fakat bu hal, uzun müddet devam edemeyeceğinden ilerde ortaya çıkacak menfaatler, bu zararları telafi etmeye kaynaklık edebilir...(Cavid Bey, 2001: 278).
\end{abstract}

Bu ifadeler genç sanayi hipotezine benzer nitelikte olsa da İktisat İlmi’nin sistematiği ve korumacılık konusunda yukarıda anlattığımız bölümlerde Mehmed Cavid Bey'in tavizsiz bir karşı tavır sergilediği dikkate alındığında aslında bu argümanı kabul ettiğini söylemek pek de mümkün değildir.

Son olarak Kılınçoğlu (2012: 115)'nun da dikkatini çektiği üzere Mehmed Cavid Bey'in liberal iktisat ilkesini mutlak anlamda önermemesi, uluslararası ticaret anlaşmaları yoluyla ticari ilişkilerin tesisini elzem görmesine bağlanabilir. Bu bağlamda XIX. yüzyılda Osmanlı Devleti ve Avrupa ülkeleri arasında imzalanmış ticaret anlaşmalarına ${ }^{11}$ kitabında yer verdiği ve açık bir şekilde bu anlaşmalara ilişkin görüşlerini ifade etmemesine rağmen bu bölümlerin uluslararası ticaretin yararlarına ilişkin bölümden sonra yer aldığı dikkate alındığında söz konusu anlaşmalardan yana olduğu üstü kapalı bir şekilde kabul edilebilir:

\begin{abstract}
“...serbest mübadele ile himaye usulü arasında orta sınırı teşkil eden ticaret antlaşmaları, yani gümrük tarifelerinin bu antlaşmalarla tayin edilmesi usulü buna üstün sayılmaktadır. Milletlerarası bir ticari yakınlığı meydana getirmek için, şimdiki durumda ticaret antlaşmaları en tesirli çare gibi kabul edilmektedir. Bu antlaşmalarda yalnız ithalat ile meşgul olunmayıp ihracat, posta, gemi seferleri, edebi ve sınai mülkiyet ile şahısların karşılıklı mevkileri de konu edilir. Antlaşmalara ek olarak da ayrıntılı olarak anlatılan gümrük tarifeleri düzenlenir. Antlaşmanın devam müddetince...bu tarifeler değiştirilemez, ticari münasebetler muntazam ve sabit bir şekilde devam eder. Bu antlaşmalarda benzerini yaparak karşılık verme ve misilleme esasına uyulur; yani müteşebbis olan iki taraftan biri diğerinin revaçtaki bir malına az vergi uygularsa, diğeri de ötekinin aynı malına değil, en revaçlı olan diğer bir malına karşı böyle bir müsaadede bulunur..." (Cavid Bey, 2001: 280).
\end{abstract}

\title{
SONUÇ
}

Mehmed Cavid Bey, Osmanlı iktisadi düşünce tarihinde liberal iktisadi görüşün sembol ismi kabul edilmektedir. Liberal iktisat lehinde ileri sürdügü argümanlar teorik tutarlılığa sahip niteliktedir. Bununla birlikte, korumacılık karşıtı olarak ileri sürdüğü argümanlar dikkate alındığında iktisat politikası tercihinde korumacılık-serbesti tartışması noktasında teorik tutarlılığı gözden kaybolmaktadır. Bu kapsamda borçlanmaya ilişkin argümanlarının korumacılığın zorunlu olduğunu gösterdiği belirtilebilir. Mehmed Cavid Bey, zorunlu yatırımlar için devletin borçlanmasını kabul etmiştir. Burada korumacılık, devletin borçla elde edilen kaynakları belli sektörleri oluşturmak üzere kullanmasıyla piyasaya müdahalesi olarak anlaşılabilir. Başka bir tutarsızlık liberal iktisat uygulamalarının faydalarına ilişkin argümanlar ve korumacılık lehindeki argümanlara karşı da serbesti lehinde ayrıntılı açıklamalarla dolu argümanlar ileri sürdükten sonra genç sanayi hipotezine benzeyen korumacılık lehinde görüşler ortaya koymasıdır. Bu durum, istisnai durumlara münhasır olduğunun belirtildiği dikkate alındığında Mehmed Cavid Bey'in korumacılığı kabul ettiği

\footnotetext{
${ }^{11} \mathrm{Bu}$ anlaşmalar çerçevesinde Osmanlı Devleti'nde izlenen gümrük politikasının tarihsel seyri için $b k$. Toprak (2019, "Korumacılık ve Milli Dış Ticaret Politikası" başlıklı bölüm).
} 
değerlendirilmesinde bulunmaya imkân vermese de İktisat İlmi başlıklı kitabının sistematiği boyutundan bakıldığında ise tutarsızlığa yol açmaktadır.

Mehmed Cavid Bey'in liberal iktisada ilişkin argümanları ve korumacılık lehine görüşlere karşı açıklamalarında ortaya çıkan tutarsızlık uluslararası ticaret anlaşmaları yoluyla ticari ilişkilerin tesisini elzem görmesiyle birlikte değerlendirildiğinde liberal iktisat ilkesini mutlak anlamda önermediği değerlendirmesinde bulunmak mümkün hale gelmektedir. Böylece Mehmed Cavid Bey'in Osmanlı iktisadi düşünce tarihinde iktisadi liberalizmin sembol ismi olarak nitelendirilmesinin yerinde bir değerlendirme olmadığı ve bu konuda ihtiyatlı olunması gerektiği söylenebilir.

\section{KAYNAKÇA}

Akyiğitzade, M. (2016). Osmanlı'da Modern İktisadın İzinde 2: İlm-i Servet. (Eds.) G. C. Albayrak, H. Genç ve S. Ç. Kocakaptan. İstanbul: Dergâh Yayınları.

Aspromourgos, T. (1996). On the origins of Classical Economics: Distribution and value from William Petty to Adam Smith. New York and London: Routledge.

Bilir, H. (2019). İktisadın bir "bilim” olarak ortaya çıkışında doğa bilimlerinin etkisi. Kebikeç, $48,175-94$.

Bozkurt, A. D. (2019). Geç dönem Osmanlı Imparatorluğu'nda iktisadi düşüncenin gelişmesinde liberal iktisat ve milli iktisat yaklaşımlarının etkisi: Karşılaştırmalı bir inceleme (1800-1914) (Yayınlanmamış doktora tezi). Gazi Üniversitesi Sosyal Bilimler Enstitüsü, Ankara.

Bozpinar, C. (2018). Osmanlı Devleti'nde iktisadi zihniyet ve sanayileşme sorunsall: Bursa ipek sektörü örneği (Yayımlanmamış doktora tezi). Hacettepe Üniversitesi Sosyal Bilimler Enstitüsü, Ankara.

Cavid Bey, M. (2001). İktisat ilmi (İlm-i İktisad-Mekteb-i İdadiye Mahsus). (Çev. S. A. Çakmak). İstanbul: Liberte Yayınları.

Cengiz, S. A. (2012). Maliye Nazırı Mehmet Cavid Bey Dönemi (1908-1926) iktisadî-malî görüş ve uygulamaları (Yayımlanmamış yüksek lisans tezi). İstanbul Üniversitesi Sosyal Bilimler Enstitüsü, İstanbul.

Devellioğlu, F. (1978). Osmanlıca-Türkçe ansiklopedik lûgat. Ankara: Doğuş Ltd. Şti. Matbaasi.

Eren, A. A. (2010). Adam Smith'in ticarete ve Merkantilist politikalara yaklaşımı: Yeni bir Adam Smith sorunu mu? İçinde Kapucu, H., Aydın, M., Şiriner, İ., Morady, F., and Çetin, Ü. (Eds.). Politik Ikktisat ve Adam Smith. London: IJOPEC Publication, 93-114.

Eren, A. A. (2011). Sir Willam Petty: Merkantilist bir düşünür mü? Ekonomi Yaklaşım, 79 (22), 45-70.

Johnson, E. A. J. (1937). Predecessors of Adam Smith: The growth of British economic thought. New York: Prentice Hall.

Kanar, M. (2008). Osmanlı Türkçesi sözlüğ̈̈. İstanbul: Say.

Kılınçoğlu, D. T. (2012). The Political Economy of Ottoman Modernity: Ottoman Economic Thought During The Reign of Abdülhamid II (1876-1909) (Doktora tezi). Princeton: Princeton University.

Mandel, E. (2008). Marksist Ekonomi el kitabı (3. baskı). Ankara: Maki Basın Yayın (Özgür Üniversite Kitaplığı). 
Murphy, A. E. (2009). The Genesis of macroeconomics: New ideas from Sir William Petty to Henry Thornton. New York: Oxford University Press.

Redman, D. A. (1997). The rise of Political Economy as a science: Methodology and the Classical Economists. London: MIT Press.

Rothbard, M. N. (1995). Economic thought before Adam Smith: An Austrian perspective on the history of economic thought (vol. I). Alabama: Edward Elgar Publishing.

Sayar, A. G. (2013). Osmanlı İktisat Düşüncesinin Çă̆daşlaşması (5. baskı). İstanbul: Ötüken Neşriyat.

Steiner, P. (2003). Physiocracy and French Pre-classical Political Economy. In Samuels, W. J., Biddle, J. E., and Davis, J. B. (Eds.). A companion to the history of economic thought. Oxford: Blackwell Publishing, 61-77.

Toprak, Z. (2019). Türkiye'de Milli İktisat: 1908-1918. İstanbul: Türkiye İş Bankası Kültür Yayınları.

Ulutan, B. (1978). İktisadî doktrinler tarihi. İstanbul: Ötüken Neşriyat.

Zanaat. (t.y.). İçinde Türk Dil Kurumu Güncel Türkçe Sözlük. Erişim http://sozluk.gov.tr. 